\title{
Critical Discourse Analysis and Identity
}

Karin Zotzmann and John P. O’Regan

\section{Introduction}

The concept of identity is of interest to applied linguistics for a variety of reasons. It links the level of the individual with the social and thus allows us to capture the processes by which individuals affiliate with or distance themselves from particular communities, what kind of information they aim to convey about themselves and how this information in turn resonates with the ideas others hold about them. Identity is hence, as Anna de Fina (2006: 263) describes it:

crucially, about conveying to one another what kind of people we are; which geographical, ethnic, social communities we belong to; where we stand in relation to ethical and moral questions; or where our loyalties are in political terms.

More specifically, and closer to one of the central concerns in applied linguistics, the concept of identity ties in with the view that language use is not only a cognitive endeavour but likewise an immanently social one. The concept sensitises us to think about the reasons for and the conditions under which people use language, the way they are perceived by others as users of language, the meanings they want to convey in particular situations and the resources they draw upon in order to do so. 
Identity is to a large extent a discursive phenomenon, as representations of self and other are co-constructed through language and other semiotic resources. It is also a material phenomenon in being enacted in time and space, in real settings (including when online), and as a consequence of actual events: individuals do not take up identities context free. It involves acts of embodiment as individuals perform and display their identities (e.g. through fashion, cosmetics, or their latest car or avatar). Individuals, however, do not enter these subjectivities on equal terms. Apart from inter-individual differences in capabilities, they vary in terms of their social position and concomitant access to linguistic, cultural, economic and other resources - social and material - that grant them different degrees of recognition. More importantly, though, classifications of self and other are largely influenced by discourses about social groups that are produced and re-produced at different levels of society and in different social spheres, e.g. the media, education and politics. These discourses, in turn, are influenced by and impact on social structures and divisions in a variety of ways.

As identity constructions are imbued with power relations and ideology, Critical Discourse Analysis (henceforth CDA) seems to be an appropriate choice for the conceptualisation and analysis of these processes. CDA, like Poststructuralist Discourse Analysis (PDA), is predicated on the idea that discursive and social processes are intricately related (see Baxter this volume). CDA, however, aligns not only with poststructuralist, but also other sociolinguistic perspectives that do not focus upon 'language or the use of language in and for themselves, but upon the partially 
linguistic character of social and cultural processes and structures' (Fairclough and Wodak 1997: 271). What makes CDA distinctive is its explicit commitment to a critique of problematic social practices with a view of transforming them for the better (Fairclough and Wodak 1997; Titscher et al. 2000). Analyses conducted in this transdisciplinary field hence usually contain a normative component. In this vein, respective authors in CDA aim to open up alternative viewpoints on and explanations of particular social phenomena, which in turn are a pre-condition for alternative courses of action. CDA is based on the conviction that there is no neutral and valuefree social science and claims about the apolitical nature of linguistic analysis are regarded to be themselves ideological, i.e. they conceal their own political interests (Fairclough 1996; de Beaugrande 2001).

This, however, is as far as commonality across approaches to CDA reaches. Although the field incorporates a range of shared fundamental assumptions and research interests, it is neither constituted by a homogeneous theoretical framework, nor by a set of fixed methodological tools. Instead, each individual research project fine-tunes its theoretical and conceptual framework as well as its methodology to its object of investigation, among them the formation, representation and enactment of identity. While this diversity of approach shows that CDA is multiperspectival and not wedded to one-dimensional interpretations of reality and truth, it generates a challenge when writing about identity and language from a CDA perspective. Given the limited space available, we have therefore decided to concentrate our attention on the work of two prominent representatives of the field of CDA: the discourse-historical approach developed by Ruth Wodak and her collaborators (Wodak et al. 1990; Wodak et al. 
2009; Wodak and Meyer 2009) and the dialectical-relational approach of Norman Fairclough (2003, 2010, 2014; Fairclough, Jessop and Sayer 2004).

We begin by describing the motivation behind the emergence of CDA, the research interests it has and the key constructs it employs, prominent among these are 'discourse', 'power' and 'ideology'. All three concepts are in need of conceptual clarity as they are not only core to this field but have also enjoyed widespread use and a concomitant range of understandings in other areas of the social sciences and humanities. These theoretical constructs, in turn, depend upon particular epistemological and ontological positions that differ across authors and which also need to be elaborated and explained. In the second part of the chapter we draw upon the existing body of research and theorisation of the discourse-historical and the dialectical-relational approaches in order to give an account of the kinds of questions that are asked, the theoretical perspectives involved, and the methodological tools employed in the analysis of objects of research in these two varieties of CDA and how these could be of assistance for language and identity research in applied linguistics.

\section{Overview of CDA}

Historical emergence, research interests and transdisciplinarity

CDA is not a discipline but a problem-oriented field with a specific transdisciplinary research program - i.e. applied social science - that develops its own theoretical 
frameworks and methodologies in relation to concrete objects of research

(Chouliaraki and Fairclough 1999; Titscher et al. 2000; O'Regan 2014). Historically, CDA emerged out of the field of critical linguistics, which was formulated by a group of scholars in the 1970s - Roger Fowler, Robert Hodge, Gunther Kress and Tony Trew - who wanted to overcome what they saw as the artificial disciplinary boundaries between linguistics and social theory (Fowler et al. 1979). The authors were interested in how the social influences the way we use language and how language in turn, contributes to the organisation and transformation of the social. Critical discourse analysts continue to elaborate and refine theories at this disciplinary interface and have engaged with and incorporated influences from, for example, systemic functional linguistics, pragmatics, conversation analysis and sociolinguistics, as well as the following:

- Michel Foucault's $(1972,1980)$ perspective on discourse;

- Karl Marx's (1977) critique of capitalism;

- Mikhail Bakhtin's $(1981,1986)$ view of genre, dialogicality and intertextuality;

- Louis Althusser's (1971) approach to ideology;

- Antonio Gramsci's (1971) theory of hegemony;

- The Frankfurt School's (Horkheimer 1976; Habermas 1984, 1987) Critical Theory;

- Bourdieu's $(1984,1988)$ concept of habitus and field;

- Roy Bhaskar's $(1986,1989,1998,2008)$ philosophy of Critical Realism. 
Differences in theoretical alignments with these and other sources as well differences in concrete research interests have also generated a variety of strands of CDA, including the:

- Discourse-historical (Reisigl and Wodak 2009);

- Socio-cognitive (Chilton 2004; van Dijk 2008);

- Social semiotic (Kress and van Leeuwen 2001; Kress 2010);

- Dialectical-relational (Fairclough 2001, 2010, 2014).

Key concepts: discourse, power and ideology

The term 'discourse' and the notion of 'critique' are not only core to CDA but also many other research areas in the social sciences and humanities. As these terms carry a wide range of vague and sometimes even contradictory understandings (Poole 2010), it is essential to clarify the specific meanings of discourse and critique in CDA. For the term 'discourse' we proceed from the general to the specific, beginning with a common distinction drawn between discourse as an abstract noun and as a countable noun, over particular features attributed to discourse to the theoretical underpinnings of the concept. In relation to 'critique', under the account of the dialectical-relational approach, we outline the difference between a normative and an explanatory function that will lead us into a wider understanding of the social ontology underlying the perspectives reviewed here. 
Discourse as an abstract noun can be understood as 'language in use', or 'talk and text in context' (van Dijk 1997: 3), a perspective that acknowledges that the contexts of production, distribution and reception influence the make-up of concrete textual instances and that these texts, in turn, have an effect on social reality. Discourse - or more generally 'semiosis' as meaning-making processes and the resources that are used for making meaning - is hence always socially embedded, i.e. it is produced, distributed and interpreted by individuals, groups or institutions in concrete historical and situational contexts. It is also inherently dialogical and intertextual, i.e. agents draw upon and mix a variety of existing linguistic and other semiotic resources in order to make meaning and to position themselves in ongoing conversations, of both an oral and a written nature. In sum, discourse is something that people do, i.e. a form of social practice. Discourse as a countable noun, in contrast, refers to either the use of language in different social domains ('media discourse', 'political discourse', 'academic discourse') or ways of representing a part of the world from a particular perspective, for instance, 'neoliberal', 'racist' or 'sexist' discourse (Fairclough 2003: 26). As there are potentially infinite representations of the world there is an equally infinite number of ways of classifying and naming discourse perspectives.

The notion of discourse is profoundly influenced by the work of the French philosopher Foucault (1972). Foucault developed his theory of discourse in response to an orthodox version of Marxism that regarded economic relations as prior to any cultural formation. From an orthodox Marxist perspective unjust economic relations ('structure') generate an ideological belief system ('superstructure') that helps to sustain the conditions that gave rise to it. Foucault rejected the dualist Marxist 
representation of ideology as a 'false consciousness' which could be made to stand in contrast to a hidden 'truth', and viewed - in a manner similar to other poststructuralist writers such as Jean-François Lyotard (1984) and Jacques Derrida (1976) - the conception of truth itself as misleading, because 'truth' by implication promotes to the level of universality what is in effect simply a claim. Moreover, the universalising pretensions of such claims are viewed as potentially oppressive and totalising as they close down and efface alternative claims (see Baxter this volume). Foucault (1972) posited instead that truth was relative to discourse, which he understood to be a body of statements and social practices that have been organised in regular, systematic ways. These discursive formations, or 'regimes of truth', are governed by their own internal rules and cut across social divisions. They are complex and distributed in objects (i.e. buildings for particular institutions such as psychiatric hospitals), relations (i.e. the separation between the 'mad' and the 'normal' or 'rational') and texts (i.e. administrative forms and regulations); they are also embodied and enacted by agents occupying identity-inscribed 'subject positions'.

From this perspective individuals are never entirely 'dominated' or 'oppressed' by economic exploitation and a concomitant alienating ideology. Instead, they are objects and agents of discourse as discourse operates through their forms of being, valuing and acting, a process Foucault (1982) called 'subjectification'. Consequently, there is no escape from 'power' as 'it is always already present, constituting that very thing which one attempts to counter it with' (Foucault 1980: 82). Conceptually, this means that the term discourse is preferred over the concept of ideology as analysis along 
these lines is not so much interested in how power is enacted through discourse but rather how it is enacted in discourse as the actual site of contestation.

While the idea that discourse is imbricated with power relations is accepted by CDA researchers, the idea that reality may be reduced to discourse is not and many continue to see language as having a referential as well as a representational function in relation to a non-discursive reality. In addition to this, they hold onto the idea of truth and to the concept of ideology as a deviation from it. Ideology is regarded as a collection of historically contingent claims to truth that are presented as 'common sense' and therefore as taken-for-granted or uncontested ideas.

Without determining people's thinking or acting in a mechanistic way, ideological assumptions nevertheless encourage individuals to act in specific, albeit constrained, ways that benefit dominant social groups. In the concrete historical moment we find ourselves in, social justice, democracy and ecology are for instance under threat because the interests of wealthy individuals and groups are advanced while the interests of the majority are marginalised and the common good neglected. Revealing the often opaque workings of power in, but also through discourse is hence one of the main goals of CDA: 'CDA is not, as one might assume, just a critique of discourse, it is a critique of the existing social reality (including its discourse) which begins with a critique of discourse' (Fairclough 2014: 5; see also Gee 2005; Reisigl and Wodak 2009). 


\section{Two approaches to $C D A$}

The discourse-historical approach

The discourse-historical approach (henceforth DHA) is, as with all other CDA variants, transdisciplinary and critical. This means that it attempts to unravel contradictions, dilemmas and manipulations in concrete oral or written textual instances with the ultimate aim to contribute to an improvement of ethically and politically problematic situations. DHA is hence not interested in how individuals construct their identity per se but in discourses - as part of wider socio-historical processes - that are problematic in the way they represent groups of people such as, for instance immigrants or women. It is distinctive in its emphasis on detailed linguistic (rhetorical, argumentative, pragmatic and semantic) analysis of empirical genre-texts.

In relation to the topic at hand Wodak and her colleagues depart from the assumption that identity processes revolve around the creation of sameness and difference through concrete discursive strategies. In their work on national identity, for example, they follow Benedict Anderson's (1983) view that 'the nation' is an 'imagined community', i.e. a construct based on mythicised recollections and narratives that suggest a common origin and set of beliefs, traditions and values. In other words, nationalist discourse projects an image of people as being of the same kind ('nationals') and different from another kind (citizens of other nation state, 'foreigners' or 'immigrants'). What is essentially a relational process and hence always in the making is presented here as static and fixed. The construction of 
nationhood is viewed by the DHA as an ideological strategy that is employed politically in order to create boundaries and to justify practices of inclusion and exclusion: it overemphasises cultural similarity within nation states and differences with other national 'peoples' while at the same time downplaying shared similarities amongst human beings as well as heterogeneity within national borders. The differences are usually linked to positive evaluations of the in-group and negative evaluations of the out-group:

Difference which is linguistically constructed through strategies of dissimilation, and which in reference to marginalised groups of others is frequently portrayed as deviance from a preferred norm, here does not usually introduce subtle distinctions, but, on the contrary, implies the affixing of undifferentiated and usually derogatory labels on the group concerned (Wodak et al. 2009: 33).

Wodak et al.'s $(1990,2009)$ research on Austrian national identity, for example, analyses contemporary constructions of the past at the service of political action in the present and future. 'Being Austrian' is regarded, from this perspective, as historically and socially constituted; it is reinforced through a variety of social practices, from elite to life-world discourses, and constantly re-interpreted and re-articulated in relation to contemporary political occasions and (geo)political transformations, such as for instance, the fall of the Iron Curtain and subsequent immigration from East European countries, the commemoration of the Nazi past, Europeanisation and globalisation. Although the construction of Austrian national identity is an object of investigation in itself, it also serves as an example of how similarity and difference 
are generally constructed through discourse. On the basis of a close-knit analysis of empirical texts that moves between data and theory in a hermeneutic circle, analysts usually draw upon different but interrelated genre-texts that revolve around the same content. For the case of migration (and hence the representation of migrants) these can include for example media reports, policy papers, legislation and election campaign materials (Wodak 2014). In order to relate texts to the particular socio-historical context they respond to and in which they are situated, analysts draw upon a layered four-level model that includes an account of the socio-political/historical context (e.g. the historical development of migration policies in a particular nation state), the current context (discussions dominating the public debate), the co-text (text-internal elements and relations), intertextual (links to other texts and voices), and interdiscursive relations (the links established between different discourses and genres). This layered contextualisation of particular genre texts provides, according to Angel Lin (2014: 217), 'a powerful methodology to explain why macrostructures of inequality are persistent and pervasive and can get reinforced and perpetuated via discursive processes across multiple sites and multiple texts over a sustained period of time'.

Wodak and her team provide a detailed methodological and conceptual framework that can be employed and amended through other empirical studies on identity at different historical junctures and in different contexts. They have compiled, for instance, a taxonomy of discursive macro-strategies and sub-strategies that are employed together with particular argumentation patterns in the discursive formation of national identity. Strategies are understood as actions in pursuit of particular 
objectives but these actions do not have to be 'planned to the last detail, or [be] strictly instrumentalist; strategies can also be applied automatically' (Wodak et al. 2009: 32). Instead, intentionality depends on a variety of factors, among them the particular genre and contexts agents engage with and in. Political speeches are, for instance, usually prepared ahead of the event and with more strategic objectives in mind than participation in a conversation. The macro-strategies Wodak et al. identify include strategies of:

- Construction: The nation is constructed as a unified entity that is associated with particular characteristics (usually superior to those of the out-group) and positive values such as, for instance, solidarity. The sub-strategy of justification helps to present problematic historic events in less problematic, or sanitised, ways that are in accordance with the positive image of the in-group;

- Transformation: Modifications and adaptions of an established identity construct in response to the particularities of the situation;

- Deconstruction: The dismantling of parts of an existing identity construct without the provision of new elements.

These can occur separately or in diverse combinations in concrete textual instances and are supported by broader sub-strategies like the emphasis or presupposition of sameness (the construction of temporal, interpersonal or territorial similarity in relation to the above) and the emphasis of difference (the construction of temporal, interpersonal or territorial dissimilarity). 
As Lin (2014: 217) points out, this elaborated methodological framework is a definite strength of DHA. The difficulty it generates especially for novice researchers is that the 'largely linguistic analytical focus $[\ldots]$ does not also equip the analyst with the social theoretical frameworks to connect the linguistic analysis to the analysis of social practice'. Fairclough's approach to CDA, in contrast, is characterised by elaborate theorisation of the links between the social and discursive analysis. For the same reason it can also be more difficult to operationalise in terms of micro-linguistic analysis. It is principally for this reason that we dedicate a longer section to the theoretical conceptualisation and methodological procedures of this variant of CDA.

The dialectical-relational approach

The dialectical-relational approach (henceforth DRA) is principally associated with Fairclough's more recent work (2010, 2014; Fairclough, Jessop and Sayer 2004; Fairclough and Fairclough 2012). His approach is probably most clearly distinct from poststructuralism as it is based on the fundamental idea that even though we apprehend reality to a large extent discursively, not all elements of the social are discursive in nature. While many poststructuralists probably would not deny this, the explicit focus on the construction of the social through discourse marginalises elements and causal relationships that are not manifested in discourse:

... the problematic methodological implication of this line of thinking when translating these abstract arguments to research is that structural issues tend to be analyzed primarily in terms of individual experiences and related understanding of them, to the detriment of the analysis of unrecognized 
structural impediments and their relationship with individual agency

(Martinez, Martin and Marlow 2014: 454 - 455).

Fairclough derives his present perspective largely from the critical realist ontology of Bhaskar (1986, 1989, 1998, 2008). Critical Realism (CR) assumes - in contrast to social constructionism - that the world exists independently of our knowledge of it, hence we might 'construe' but we do not 'construct' the world: 'natural systems endure and act outside the conditions that enable us to identify them' (Bhaskar 2008: 13). This also applies to the social world. Even though social reality is mediated through discourse, there are other elements of the social that are causally effective but distinct from discourse, for example, social structures and relations, values, desires and material conditions (Chouliaraki and Fairclough 1999). These elements of social life are dialectically related, i.e. each moment 'internalizes the others without being reducible to them' (Fairclough 2001: 232). Technological systems such as, for example, an urban transportation system are both semiotic and material, i.e. they have a material base but they are also designed on the basis of knowledge that is available at a specific point in time. Transportation systems are, however, more material than, for example, identities, which tend towards the more semiotic or discursive end of the spectrum. This does not mean though that identities can be reduced to discourse alone. Their articulation depends, on the one hand, on the embodied self and agency of an individual and, on the other hand, on material reality and structures as 'the enduring, affording and constraining influences of the social order' (Sealey and Carter 2004: xiii). From a CR perspective people and pre-existent structures interact with each other on the basis of their distinctive powers. The results of this interaction 
might not be predictable but they can be causally effective and thus, potentially, explicable (ibid:: 12).

In order to account for causality, CR distinguishes between the 'real', the 'actual' and the 'empirical' as 'three overlapping domains of reality' (Bhaskar 2008: 56). The 'real' consists in naturally existing and enduring objects, including not only material objects such as means of transportation and buildings, but also institutional structures, human agents or partly enduring and institutionalised discourses, such as racism or sexism. Their common characteristic is that they are endowed with causal powers, i.e. 'generative mechanisms underlying empirically observable phenomena' (Sealey and Carter 2004: 68) that exist independently of the observer. This does not necessarily mean that they are always causally effective. A car for instance has 'real' powers but these are actualised only when it is turned on and moving. The 'real' is thus different from the 'actual' - the activation of powers in events that make a difference (such as driving), which in turn is different from the 'empirical' - the domain in which experiences are apprehended (Bhaskar 2008; Fairclough, Jessop and Sayer 2004). The real, the actual and the empirical therefore exist in a nested relationship with one another.

This stratified ontology allows the analyst to capture causally effective powers that might/might not be actualised in actual events and might/might not be recognised by agents and made salient in their discourse. To remind us, if we focused our analysis on the discursive construction of reality, i.e. on what is present, it would be difficult to 
capture 'the unsaid, the unknown, the absent and what may lie in potential' (Martinez, Martin and Marlow 2014: 456). The same authors provide an example:

... an institution or organization may have an implicit culture of sexism and racism in relation to career progression and the allocation of financial rewards, yet these mechanisms may not be perceived by those benefiting from them, and unacknowledged by those perpetuating them. However, the transfactuality [i.e. the absence at the empirical level] of mechanisms of privilege and discrimination means that they operate whether or not they are acknowledged to exist. It also explains why, within the same organisation, individual women and people of colour might advance, but the demographic composition of the management structure remains predominantly white and male. Though the overall tendency of the structure is governed by the dominant mechanisms of sexism and racism, discriminatory mechanisms may not be actualized in all cases, and other mechanisms — say, a corporate call for diversity or an equal opportunities policy — may potentially provide some countervailing forces (ibid.: 457).

CR's stratified ontology draws attention to contextual constraints and affordances that potentially could, and those that actually do, influence individuals and their projected or ascribed identities. It effectively links the concept of identity with discourse as well as agency and structure and can thus sensitise the analyst to the unequal distribution of linguistic, cultural and economic resources, as well as locate semiotic processes 
'within the practical engagement of embodied and socially organised persons with the material world' (Fairclough, Jessop and Sayer 2001: 7).

For Fairclough, an account of the relational and stratified whole within which social problems are nested, is crucial, as he aims to move beyond 'normative critique' - the critical analysis of discourse and texts - to 'explanatory critique' (Bhaskar 1998) - i.e. critique that attempts to account for causality, which in turn is a precondition for transformative social action. Whereas normative critique de-constructs ideological assumptions and false beliefs, explanatory critique tries to explain the fact that despite their inherent shortcomings, a respective representation is still in place or false belief is still held. In other words, 'it involves [...] an explanation of the reproduction of the account as an accepted and "lived" body of beliefs, which necessitates a mode of substantive sociological explanation' (ibid.: 121).

The concept of 'interdiscursivity’ (Chouliaraki and Fairclough 1999; Fairclough 2010) is essential in this context. Interdiscursivity refers to the dialectical relations between discourses (as ways of representing), genres (as ways of acting and interacting) and styles (as ways of being). When power relations shift, relations between discourses, genres and styles change and are differently drawn upon. Discourses in this sense are seen as responsible for enacting new genres that may then be inculcated as new styles - i.e. as identities in their semiotic aspect: 'as new ways of being, new identities, including both new styles and new bodily dispositions' (Fairclough, Jessop and Sayer 2004: 34). It is therefore at the dialectical nexus of 
discourses, genres and styles that identity becomes a salient object of analysis in itself, because it is as a result of changing discourses that new genres and therefore new identities may come into play. To take an example, $9 / 11$ as a generative event set in train a whole series of discursive changes (e.g. in the form of new discourses of security and public hypervigilance) that have enacted new ways of (inter)acting and inculcated new identities and subjectivities. These can be found in heightened airport security protocols, stricter border controls, revised immigration laws, reformulated attitudes to freedom of speech, newly promulgated policies on multicultural relations and 'deradicalisation'. In each of these circumstances new genres are set in motion that set up a range of new subject positions, or identities, by which individuals are expected to act and interact. In identity terms - but not only these - it matters a good deal that individuals engage with these new genres as they are expected to. For example, in the panopticon of security hypervigilence, which many of us live in today, individuals are being required to take up particular subject positions, often - as in the case of airport security protocols and border controls - with the threat of coercion and even punishment if they do not. The process of changes in discourses leading to new genres and styles is what Fairclough refers to as the 'operationalisation' of discourse, in which discourses are 'put into practice' (Fairclough 2010: 232). The new genres and styles which result may then be physically materialised in space as, for instance, buildings, sections, departments and centres of various kinds, i.e. as physical spaces in which genres and styles may be performed. The institutional and spatial operationalisation of discourses, genres and styles thus correspond to orders of discourse as "the social structuring of semiotic variation' (Fairclough, Jessop and Sayer 2004: 33). The different levels of social processes and their semiotic relations are illustrated in figure 1. 
<insert figure 1 here $>$

Between the levels of structures, practices and events and their respective fields and codes a dialectic is in play. Therefore, no level is discrete; it is in a constant process of flowing into and between the other elements in each of the levels. Interdiscursivity is the mediating 'interlevel' between the micro-level linguistic analysis of the text (in conjunction with relevant social analysis) and the analysis of social structures (O’Regan and Betzel forthcoming). In other words, relations of interdiscursivity via orders of discourse are what connect the analysis of the text with an analysis of social structures.

Fairclough conceives of DRA as a methodology and not just a method to be applied. Methodology is understood as theory in combination with method in the construction and analysis of an object of research (Bourdieu and Wacquant 1992; Fairclough 2010). In this sense it is not simply a matter of taking a method and applying it to an object of research. The object first has to be theorised itself drawing upon relevant social theories in a 'transdisciplinary way', 'either in research teams which bring together specialists in relevant disciplines, or by engaging with literature in such disciplines' (Fairclough 2010: 236). Hence, 'not only are research questions essential to research, but there is also the need of a thorough understanding of the reality on which research acts' (David Block, personal communication, 26.03.2015). In this process the object of research is constructed. Having done this, the task is to seek a 
'semiotic point of entry' into what are usually the written or spoken texts which circulate as social practices within the order of discourse that corresponds to them and which act as interdiscursive cues. The principal purpose is to identify and discuss the linguistic features of texts that appear to act as cues to interdiscursive relations. The emancipatory agenda of the DRA aims at the righting of social 'wrongs' and involves the following four stages:

1. Focus upon a social wrong, in its semiotic aspect.

2. Identify obstacles to addressing the social wrong.

3. Consider whether the social order 'needs' the social wrong.

4. Identify possible ways past the obstacles.

Space does not permit that these stages can be elucidated in detail (see Fairclough 2003, 2010). DRA is oriented to the research of topics that may be said to have significant implications for human well-being. Topics such as immigration, terrorism, globalisation, environmentalism, neoliberalism, nuclear power, global warming, racism, sexism and war all suggest themselves. Identity in one form or another arguably cuts across them all as these phenomena set discourses in motion leading to the enactment of genres and the inculcation of styles. Stage 1 asks that we focus upon a social phenomenon in its semiotic aspect. This involves seeking out a semiotic point of entry. In DRA social structures and institutions are not wholly discursive but considered to be comprised of discursive and non-discursive elements. The semiotic point of entry therefore pertains to social practices and events in their semiotic aspect 
as orders of discourse and texts (see figure 1). Once the topic is selected, the second step is to bring relevant theories to bear upon it: to theorise the phenomenon in a transdisciplinary way. In the context of this chapter and this handbook theories of identity and possibly others within a sociological, political and economic frame would be deemed suitable. In relation to the topic of the politics of multiculturalism for example, one or more theories of identity, migration, interculturalism, race, or human rights, amongst others, will be salient.

In the next stage (Stage 2) the point is to discuss the origins and causes of the phenomenon (and if a social wrong, the possible obstacles to changing it). In the topic of the politics of multiculturalism for example, the history of multicultural relations in the context under discussion will be significant as will the social and institutional contexts - orders of discourse - in which such a politics operates (e.g. political, police, legal, race relations, ethnic and religious, immigration, etc.) and their associated social events and texts (e.g. political speeches and press briefings, communiqués and policing protocols, official announcements and reports, policy procedures and documents, mission statements, news broadcasts, etc.). The next step in this stage is to select texts and the categories for their analysis, and then to carry it out. For the purposes of undertaking an analysis of texts, linguistic analysis is essential. For example, issues of foregrounding and backgrounding of agents, modality, coordination and subordination, personal deixis (e.g. we vs. they), tense, textual structure and argumentation may each be relevant (see Fairclough 2003, 2010 for more detailed accounts). It is important to note that this is not simply a tick box exercise; what linguistic features are of import, and why, will need to be argued. 
CDA - and not just DRA - also requires that we attempt to demonstrate warrant for the interpretations that we make. If the settled assumptions of the text are to be disturbed and possibly dismantled, it must be from within the 'texturing' of the text that this occurs. Opposing the arguments and assumptions of the text may be part of the reason for wanting to critique the text, but is not in itself CDA. The move to interdiscursive analysis comes through linking textual interpretation to the theoretical frame elaborated in Stage 1, as well as through consideration of relevant discursive cues to genres and styles in a dialectical movement between events and social practices, texts and the order of discourse.

Stages 3 and 4 take us further into the domain of explanatory critique in DRA. Stage 3 asks whether the existing social order - e.g. structures of capitalism, race and gender discrimination, nationalism, immigration controls, patriarchal relations etc. needs the phenomenon to be the way that it is. An example is that since the 20072008 financial crisis the UK government has imposed an austerity regime on the public finances in order to recoup the billions of pounds of public money used to rescue the British (and London-based international) banking system from collapse. Arguments proliferated about what the right response to the crisis should be but for many, including the authors of the present chapter, the crisis showed that the financialised model of neoliberal capitalism ushered in some 30 years previously under the auspices of the Conservative governments of prime minister Margaret Thatcher had been an abject failure and ought to be dismantled. Since this was - and still is - deemed politically, economically and ideologically unacceptable - i.e. the existing social order needs the system to stay the way it is - the solution to a crisis 
wrought by that failure has been the even greater dogmatic application of the neoliberal strictures that brought the crisis about. To dismantle the neoliberal hegemony directly threatens the interests of those who have gained most from it: the bankers, hedge funds, brokers, market speculators and investors in whose personal interest it is that the system is maintained, as well as the state apparatuses of political, social and coercive power that administer it: parliament, the mass media, the church, the police, the armed forces and the judiciary. Most problematically, such is the power of the neoliberal hegemony that the long term interests of the great majority of the UK population have been made to appear ineluctably tied to the shoring up of the entire rotten edifice. Identities are of course at stake too, as people wedded to the notion of being property owners for example, fixate on the fluctuations of the housing market, while those less fortunate, such as the socially marginalised and the unemployed, are systematically discriminated against and excluded. This all places considerable obstacles in the way of transformative action and change. In sum, while the dominant discourse may be contested (Stage 4), it is by no means a foregone conclusion that it can readily be overcome.

So far we have presented an overview of the key tenets of CDA and how these might be related to identity. In the following section, we turn to how CDA can assist with the study of language and identity in applied linguistics. 


\section{Issues and ongoing debates}

In recent decades the focus of attention in applied linguistics has gravitated to the concept of identity in all its multifacetedness (Block 2012). According to de Fina (2006: 262) this research on identity has been strongly influenced by a 'shift towards a social constructionist, interactionist paradigm', a concomitant anti-essentialist view of the self and attention to the micro-level of interaction and meaning making. The idea that identities are socially construed, discursively mediated, dynamic, context dependent and relational is generally embraced by the two versions of CDA reviewed here. They differ, however, both in focus and ontology. In terms of focus, they go beyond analysis of how others are represented or how people generally negotiate and construct their identity in cooperation with others. The concept of identity is of interest to CDA because it is an essential part of a social situation that is problematic, for instance when individuals or groups of people are under threat from discrimination, marginalisation and exclusion. One core strategy in these powerimbued processes is to discursively unify one's in-group, construct differences between groups, frame and polarise representation and categorise others in a derogatory way, as captured by the DHA framework reviewed above.

In terms of ontology, we have already outlined that the DHA variant of CDA does not subscribe to postmodern anti-essentialism and social constructionism. However, authors writing from both CDA perspectives do not assume that there are static essences lying behind social categories but that life is a process of change, whether in body, mind or subjectivity. Like the social constructionists, their objective is to critique discourses that label groups of people in ways that suppress difference and 
thus contribute to marginalisation, exclusion and violence. The critique, however, does not target essentialism as the core of all social ills (Friedman 2002). The problem, as Andrew Sayer (2011) has pointed out, is not the assertion of sameness or difference, but the mistaken attribution or denial of particular characteristics. Racism, for instance, is wrong on both counts, as it is based on the one hand on 'spurious claims about differences which actually have no significance, and on the other denial of differences - through the stereotyping characteristic of cultural essentialism which are significant' (p. 457). Conversely, denying sameness and 'asserting instead difference to the point of implosion into "de-differentiation" (McLennan 1995 in Sayer 2011: 455) runs into the danger of overlooking durable structures and power relations that influence individuals. Social relations are socially constructed but that does not mean that they can be changed through voluntary individual action. To the contrary, social structure is often not only durable but also resistant to social change since people do not often reflect consciously on its existence. What makes social structure particularly stable is its relation with extra-discursive patterns and elements and the fact that the social structure, 'in so far as it is appropriated by human beings, is always already made' (Bhaskar 1998: 33). But although social structure is something that individuals do not make, 'it exists only in virtue of their activity' (ibid.). As Fairclough (1992: 65) argues, discourse is thus 'firmly rooted in and oriented to real, material social structures'. Evaluations and (mis)representations of others are thus - from a CDA perspective - not exclusively based on essentialist categories in people's minds; they are linked to social, economic and political differences and injustices, which in turn are mediated, maintained or resisted through discourse. Structural marginalisation interrelates with discourse in a number of 
complex ways and impacts crucially upon the amount and quality of recognition people receive from others.

Engaging with discourse as well as social and political-economic theories seems ever more important in the current political and economic climate where inequalities are deepening in and across nation states. Over the last three decades the gap between the rich and the poor globally has widened to such an extent that the richest 85 people on the planet have accumulated the same wealth as the poorest 3.5 billion (Oxfam 2014). One strategy of wealth transfer from the public to small financial elites is to privatise and marketise public services such as health, education and transport. This redistribution of resources is accompanied by an ideology that presents society as an aggregate of individuals pursuing their private purposes according to their own private means in a context of hyper-competition (see Chun this volume).

Paradoxically, the concept of identity and meaning making processes have thus come to the forefront of academic research and debate at a time when socio-economic and political problems are increasing and identities in the late modern world are in a state of profound crisis. It is our assertion that through its engagement with discourse as well as with social, political and economic theory, CDA can play a key role in applied linguistics research on identity by relating identity processes to other elements of socio-material reality so that obstacles to ameliorative transformative action may be confronted and in time overcome. 


\section{Summary}

This chapter engages with two versions of Critical Discourse Analysis (CDA) - the discourse-historical approach developed by Ruth Wodak and her collaborators and the dialectical-relational approach of Norman Fairclough - and how these may be utilised in language and identity research in applied linguistics. It explores the normative, as well as the underlying epistemological and ontological assumptions of CDA, and gives an account of the kinds of questions that are asked, the theoretical perspectives involved, and the methodological tools employed in the analysis of objects of research in these two approaches.

\section{Related topics}

Positioning language and identity: poststructuralist perspectives; Class in language and identity research; Exploring neoliberal language, discourses and identities

\section{Further reading}

Chouliaraki, L. and Fairclough, N. (1999). Discourse in late modernity. Edinburgh: Edinburgh University Press. (This book provides the theoretical basis for CDA as a transdisciplinary approach to social research.) 
Fairclough, N. (2003). Analysing discourse: textual analysis for social research. London: Routledge. (This book serves as a handbook for doing critical discourse analysis with textual data in social scientific research.)

Fairclough, N. (2010). Critical discourse analysis: the critical study of language. 2nd edn. London: Longman. (This book is a collection of key papers by Norman Fairclough covering the period 1983-2008. It traces the evolution of CDA in its theoretical and practical dimensions.)

Fairclough, N. (2014). Language and power. 3rd edn. London: Longman. (Originally published in 1989, this is the text in which Fairclough's version of CDA was first properly formulated. This edition contains a revised introduction offering a state-ofthe-art overview of the field as well as responses to critiques which have been made.)

Wodak, R. and Meyer, M. (eds.) (2009). Methods of critical discourse analysis. 2nd edn. London: Sage. (This collection includes contributions from a range of key perspectives in CDA, including discourse-historical, dialectical relational, and multimodal.)

\section{References}

Althusser, L. (1971). Ideology and ideological state apparatuses, in L. Althusser (ed.) Lenin and philosophy and other essays. New York: New Left Books, pp. 121-176.

Anderson, B. (1983). Imagined communities. Reflections on the origin and spread of nationalism. London: Verso 
Bakhtin, M.M. (1981). The dialogic imagination. Austin: University of Texas Press.

Bakhtin, M. M. (1986). Speech genres and other late essays. Austin: University of Texas Press.

Baxter, J. (this volume). Positioning language and identity: poststructuralist perspectives, in S. Preece (ed.) The Routledge handbook of language and identity. Abingdon: Routledge, pp. x-xx.

Bhaskar, R. (1986). Scientific realism and human emancipation. London: Verso.

Bhaskar, R. (1989). Reclaiming reality: a critical introduction to contemporary philosophy. London: Verso.

Bhaskar, R. (1998). The possibility of naturalism: a philosophical critique of the contemporary human sciences. 3rd edn. London: Routledge.

Bhaskar, R. (2008). A realist theory of science. London: Verso.

Block, D. (2012). Economising globalisation and identity in applied linguistics in neoliberal times, in D. Block, J. Gray and M. Holborow (2012). Neoliberalism and applied linguistics. London: Routledge.

Bourdieu, P. (1984). Homo academicus. Paris, France: Minuit.

Bourdieu, P. (1988). Language and symbolic power. Cambridge: Polity Press.

Bourdieu, P. and Wacquant, L. (1992). An invitation to reflexive sociology. Cambridge: Polity Press. 
Chilton, P. (2004). Analysing political discourse: theory and practice. London: Routledge.

Chouliaraki, L. and Fairclough, N. (1999). Discourse in late modernity. Rethinking critical discourse analysis. Edinburgh: Edinburgh University Press.

Chun, C. (this volume). Exploring neoliberal language, discourses and identities, in S. Preece (ed.) The Routledge handbook of language and identity. Abingdon: Routledge, pp. X-XX.

de Beaugrande, R. (2001). 'Interpreting the discourse of H.G. Widdowson: a corpusbased critical discourse analysis', Applied Linguistics, 22(1): 104-121.

de Fina, A. (2006). Discourse and identity, in A. de Fina, D. Schiffrin and M. Bamberg (eds.) Discourse and identity. Cambridge: Cambridge University Press, pp. 263-282.

Derrida, J. (1976). Of grammatology [Trans G.C. Spivak]. Baltimore and London: Johns Hopkins University Press.

Fairclough, N. (1992). Discourse and social change. Cambridge: Polity Press.

Fairclough, N. (1996). ‘A reply to Henry Widdowson’s discourse analysis: a critical view', Language and Literature 5: 1-8.

Fairclough, N. (2001). 'The dialectics of discourse', Textus 14: 231-242.

Fairclough, N. (2003). Analysing discourse: textual analysis for social research. London: Routledge. 
Fairclough, N. (2010). A dialectical-relational approach to critical discourse analysis in social research, in N. Fairclough (ed.) Critical discourse analysis: the critical study of language. London: Longman, pp. 230-254.

Fairclough, N. (2014). Language and Power. $3^{\text {rd }}$ edn. [1 ${ }^{\text {st }}$ ed. 1989]. London: Routledge.

Fairclough, I. and Fairclough, N. (2012). Political discourse analysis: a method for advanced students. London: Routledge.

Fairclough, N., Jessop, B. and Sayer, A. (2001). Critical realism and semiosis.

[Online]. Paper presented to the International Association for Critical Realism annual conference, Roskilde, Denmark (17.-19.August). Available at:

http://www.criticalrealism.com/archive/iacr_conference_2001/nfairclough_scsrt.pdf

Fairclough, N., Jessop, B. and Sayer, A. (2004). Critical realism and semiosis, in J.

Joseph and J. Roberts (eds.) Realism discourse and deconstruction. London: Routledge, pp. 20-42.

Fairclough, N. and Wodak, R. (1997). Critical discourse analysis: an overview, in T. van Dijk (ed.) Discourse and interaction. London: Sage, pp. 67-97.

Foucault, M. (1972). The archaeology of knowledge. London: Tavistock Publications.

Foucault, M. (1980). The history of sexuality, vol. I. [Trans R. Hurley]. New York: Vintage. 
Foucault, M. (1982). Technologies of the self, in L.H. Martin, H. Gutman and P.H. Hutton (eds.) (1988). Technologies of the self. A seminar with Michel Foucault. Amherst: The Universiy of Massachusetts Press, pp. 16-49.

Fowler, R., Hodge, B., Kress, G. and Trew, T. (1979). Language and control. London: Routledge and Kegan Paul.

Friedman, J. (2002). 'From roots to routes. Tropes for trippers', Anthropological Theory, 2: 21-36.

Gramsci, A. (1971). Selections from the prison notebooks. London: Lawrence and Wishart.

Gee, J.P. (2005). An introduction to discourse analysis: theory and method. London: Routledge.

Habermas, J. (1984). The theory of communicative action 1. London: Heinemann.

Habermas, J. (1987). The theory of communicative action 2. Cambridge: Polity.

Horkheimer, M. (1976). Traditional and critical theory, in P. Connerton (ed.) Critical sociology: selected readings. Harmondsworth: Penguin, pp. 206-224.

Kress, G. (2010). Multimodality: a social semiotic approach to contemporary communication. London: Routledge.

Kress, G. and van Leeuwen, T. (2001). Multimodal discourse: the modes and media of contemporary communication. London: Arnold. 
Lin, A. (2014). 'Critical discourse analysis in applied linguistics', Annual Review of Applied Linguistics, 34: 213-232.

Lyotard, J.-F. (1984). The postmodern condition: a report on knowledge. Manchester: Manchester University Press.

Martinez, A.; Martin, L. and Marlow, S. (2014). 'Developing a Critical Realist positional approach to intersectionality', Journal of Critical Realism, 13(5): 447-466.

Marx, K. (1977). Capital. Vol. I. [Trans. B. Fowkes]. New York: Vintage.

O’Regan, J. P. (2014). 'English as a lingua franca: an immanent critique', Applied Linguistics, 35(5): 533-552.

O’Regan, J. P. and Betzel, A. (forthcoming). Critical discourse analysis: a sample study of extremism, in Zhu Hua (Ed.) Research methods in intercultural communication. London: Blackwell.

Oxfam (2014). Even it up. Time to end extreme inequality [Online]. Available at: http://policy-practice.oxfam.org.uk/publications/even-it-up-time-to-end-extremeinequality-333012

Poole, B. (2010). ‘Commitment and criticality: Fairclough's critical discourse analysis evaluated', International Journal of Applied Linguistics, 20(2): 137-155.

Reisigl, M. and Wodak, R. (2009). The discourse-historical approach (DHA), in R. Wodak and M. Meyer (eds.), Methods for Critical Discourse Analysis. $2^{\text {nd }}$ ed. $\left(1^{\text {st }}\right.$ ed. 2001). London: Sage, pp. 87-121. 
Sayer, A. (2011). Why things matter to people: social science, values and ethical life. Cambridge: Cambridge University Press.

Sealey, A. and Carter, B. (2004). Applied linguistics as social science. London:

Continuum.

Titscher, S., Meyer, M., Wodak, R. \& Vetter, E. (2000). Methods of Text and Discourse Analysis. London: Sage.

van Dijk, T. (2008). Discourse and context. a sociocognitive approach. Cambridge: Cambridge: Cambridge University Press.

van Dijk, T.A. (ed.) (1997). Discourse as structure and process 1. London: Sage.

Wodak, R. (2014). 'The Discursive Construction of Strangers: Analyzing Discourses about Migrants and Migration from a Discourse-Historical Perspective', Migration and Citizenship (Newsletter of the American Political Science Association Organized Section on Migration and Citizenship) 3(1): 6-10.

Wodak, R., de Cillia, R., Reisigl, M. and Liebhart, K. (2009). The discursive construction of national Identity. $2^{\text {nd }}$ edn. [ $1^{\text {st }}$ ed. 1999]. Edinburgh: Edinburgh University Press.

Wodak, R. and Meyer, M. (eds.) (2009). Methods for critical discourse analysis. $2^{\text {nd }}$ edn. London: Sage.

Wodak, R., Pelikan, J., Nowak, P., Gruber, H., De Cillia, R. and Mitten, R. (1990).

"Wir sind alle unschuldige Täter!" Diskurshistorische Studien zum

Nachkriegsantisemitismus. [Translated title in English] Frankfurt/Main: Suhrkamp. 